\title{
Report on Peter Drucker's Speech at ACRL Membership Meeting
}

\author{
Submitted by \\ Linda Beaupré \\ Coordinator of Public Services \\ Moffitt Undergraduate Library \\ University of California, Berkeley
}

In his speech at the Association of College and Research Libraries membership meeting, June 30, during the ALA Annual Conference in San Francisco, Peter Drucker outlined the fundamentals of managing a service organization. Drucker is a highly respected management consultant and author whose latest book, Management: Tasks, Responsibilities, Practices, has been accepted as a basic source of management theory. His paper, "The Management of Public Service Institutions," focused on the basic overview of an organization necessary for effective administration. At a time when many libraries are developing goals statements, Drucker's emphasis on knowing the user communities, evaluating the usefulness of library programs, and efficiently using and developing library staff is particularly appropriate.

Mr. Drucker began by telling us he was not going to speak specifically about libraries because he didn't know very much about libraries. However, as he continued he demonstrated a knowledge of the primary functions of libraries and librarians which is rarely expressed outside of the profession. He obviously uses libraries and consults with librarians, whom he characterized as people who understand the dynamics of information and act as catalysts to convert data into information.

Drucker noted that in libraries, as in other public service institutions, the fundamentals of management are often pushed aside as we deal with daily crises. One of the fundamentals is that we know our "publics." Who are the people who depend on the library and who are the people outside the library who have the power to influence the future of the library? This second public Drucker defined as any group who can stymie you, e.g., taxpayers and school boards. We must know how each group per- ceives the library, what they demand and expect from the library. Librarians' concepts of what the library should be may not correspond with the concepts of our public. We should pay continuing attention to how people use the library, and as patterns of use change, the library must change to accommodate current needs and expectations.

Secondly, we must look at what we are doing and ask, If we didn't do it already, would we start doing it? What are the results of energies spent? What can we abandon or downgrade to channel our energies in the way most appreciated by our users? Drucker indicated that often resources are wasted defending yesterday; that the less viable a program, the more energy is needed to keep it alive. He also cautioned that if we plan to start something new we should plan to phase out something old, a concept that often means difficult decisions. A new program should be handled by an experienced staff member, a proven performer, rather than someone new who hasn't been through crises within the system. As the market changes, in this case the change from predominantly liberal arts oriented colleges and universities to more professionally oriented schools, the library must change. In reviewing library operations we have to establish priorities. Since an institution cannot be a leader at everything, we must decide in which areas we can make the greatest impact. These risk-taking decisions are the responsibility of administrators who should seek input from faculty, staff, and students before committing the organization to a path of action.

Finally, Drucker turned his attention to the library staff, particularly to librarians as professionals who tend to be more interested in the profession than in their institution and who are often overtrained for the duties they are re- 


\section{BOOKS FOR COLLEGE LIBRARIES}

Second Edition

The new edition of this essential publication for college libraries comprises six paperbound volumes:

\section{Volume 1 hUMANITIES \\ 2 LANGUAGE AND LITERATURE \\ 3 HISTORY \\ 4 SOCIAL SCIENCE \\ 5 PSYCHOLOGY, SCIENCE, AND TECHNOLOGY \\ 6 INDEX}

The preparation of the Second Edition, a project of the Association of College and Research Libraries, a division of ALA, was funded by the Council on Library Resources. The nearly 40,000 titles selected are considered to be the minimum essential for the four-year undergraduate library. Subject specialists evaluated the titles in the earlier edition and titles published between 1964 and 1972. ISBN 0-8389-0178-6 \$65.00

\section{Order Department}

\section{AMERICAN LIBRARY ASSOCIATION}

50 East Huron St., Chicago, IL 60611 quested to perform. He suggested that perhaps librarians could be as effective with less education than is now required. More important, he stressed that a professional staff should be a partnership, not a hierarchy. Managers should discuss with each professional staff member what that person sees as his or her particular contribution to the institution; what are the results of his or her efforts. Drucker referred to much of what librarians do as "donkey work" involving bringing order out of the chaos of many forms of data. In order for this "donkey work" to be satisfying and for the staff member to be productive, the manager must help to focus the individual librarian's vision on the results of his or her labors.

Drucker summed up his talk with a warning. Noting that libraries, information centers, are expensive and that most users see yesterday's library, he cautioned that without the knowledge of what users want and without the users' understanding of what they are getting, we are at the mercy of accountants. In other words, if librarian/administrators do not know their publics and respond to their needs, if they do not know their institutions and make a visible impact with their programs, people who deal in figures will determine the future of our libraries.

$\square$

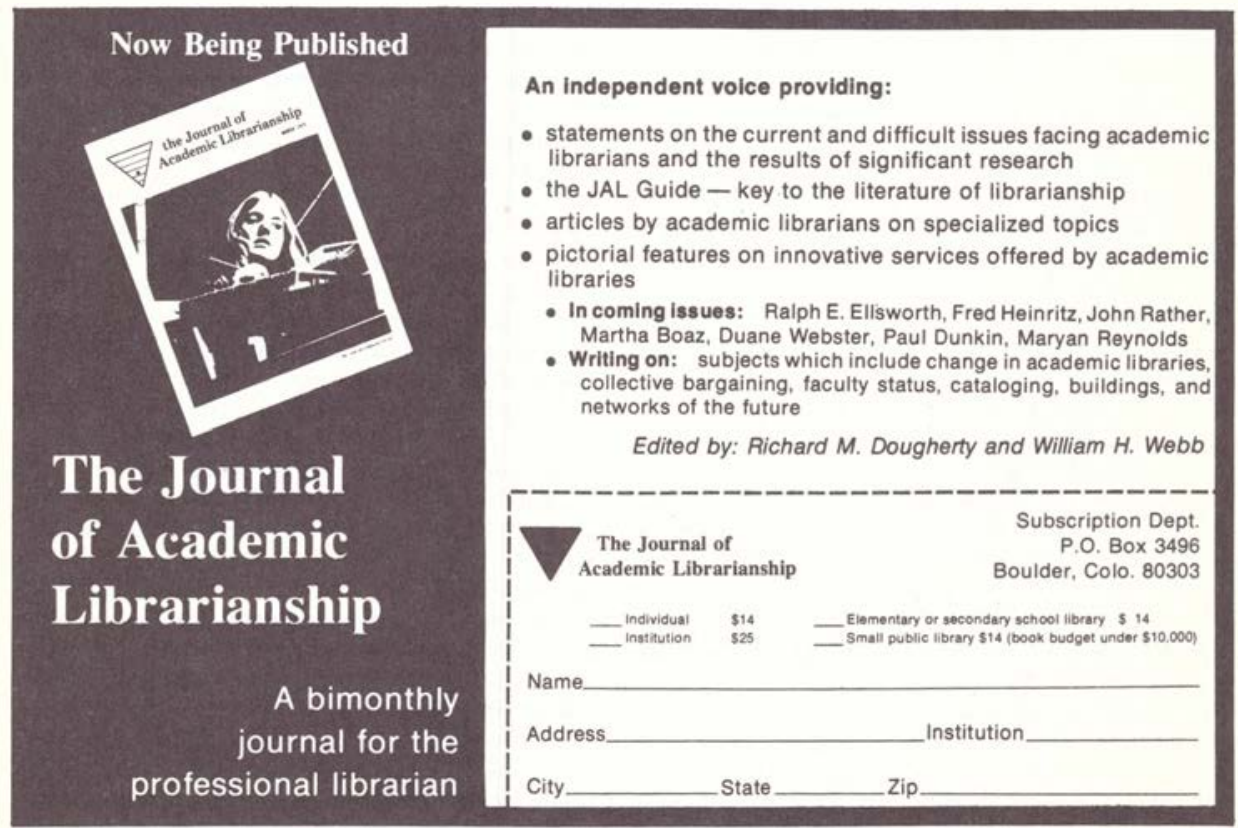




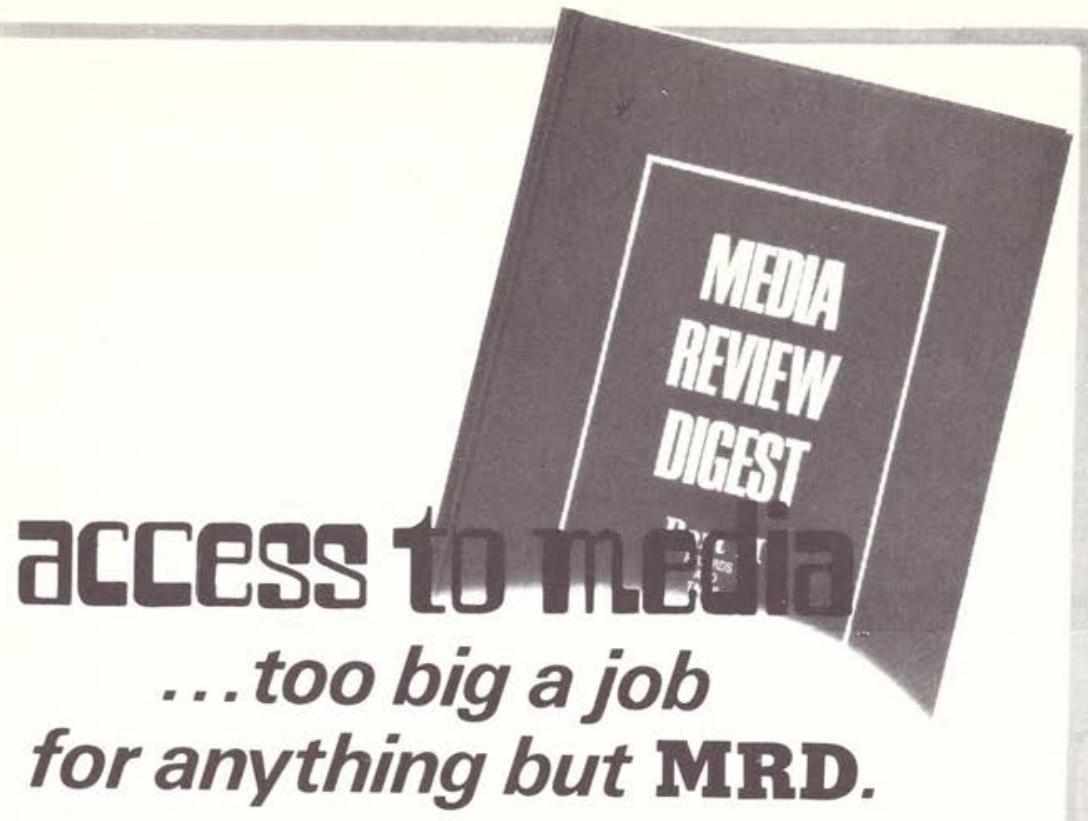

MEDIA. That's a lot of territory to cover when you need to use something special. Particularly if you don't know which medium to use, let alone what is available in each. Unless you know the right place to look. MEDIA REVIEW DIGEST is the right place to look, for nonbook media review and acquisition data on anything from feature films to games and educational toys.

MRD researches media in 204 critical review sources from PLAYBOY to RELIGION TEACHER'S JOURNAL and comes up with the hard facts every quarter - plus extras like content summaries for feature films, complete cataloging data in both Dewey and Library of Congress formats, awards and prizes section, frequent quotes from significant reviews for quicker selection, a directory of producers and distributors for one-stop acquisition, thorough cross-indexing...more than we could even list here. But don't just take our word for it. Check out the exhaustive review of MRD in the June Booklist REFERENCE AND SUBSCRIPTION BOOKS REVIEWS section, page 1087.

Then consider putting MRD to work in your media center.

\section{MEDIA REVIEW DIGEST} from.

pierian press $5 \underset{\text { ann arbort. michigan }}{5000 \text { washan }}$ 


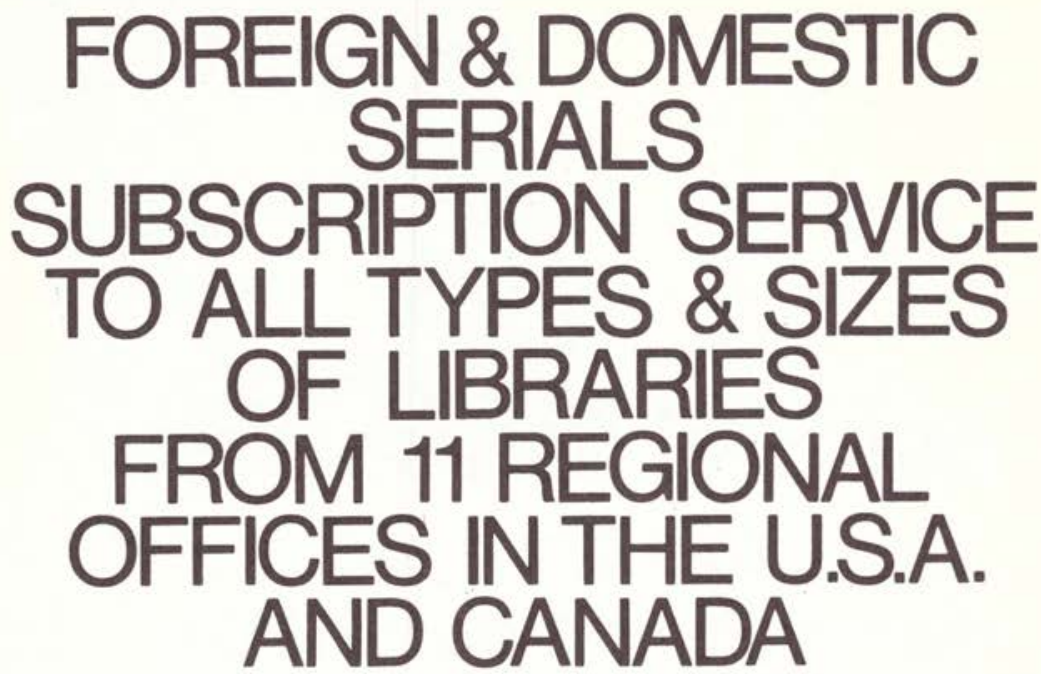

COMPREHENSIVENESS

EBSCO services periodicals, newspapers, annuals, yearbooks, irregular book/monographic series (num. bered or unnumbered), and continuations. Our computerized price file lists over 100,000 titles. However. we gladly research any title ordered and do not expect the customer to provide publisher name and ad. dress. Our research cycle is thorough and provides a quick answer if we are unable to identify the pub. lisher. We service titles from all nations of the world. The only titles we cannot (normally) service for you are order-direct by the publisher's requirement. (However, if you are a librarian who desires to place 100 per cent of all serials with a single agency, we can handle even the order-direct publishers for you.)

\section{FLEXIBILITY}

We believe what we do for you and how we do it should be determined by your needs. We have suggested procedures and formats. Our order processing and records are computerized, and we are able to employ our computer to service any special requests you may have. In the event you have a request which a com. puter, for some reason, cannot honor, we keep our typewriters handy and a perfect willingness to do what. ever is necessary to suit your needs.

\section{PERSONALIZED SERVICE}

Our network of 11 regional offices headed by General Managers with experience and authority to act guar. antees you responsiveness. Our 11 Managers have 151 years' experience among them in servicing libraries with seriais subscriptions. Order control is located at our regional office. The Manager who commits is the Manager who controls. Each of our customers is assigned to one Customer Service representative, so there is consistency in communications.

\section{WRITE OR PHONE TODAY}

\section{ESSCO}

826 South Northwest Highway Barrington. IL 60010

(312) 381.2190

\section{P.O. Box 2543}

Birmingham AL 35201

(205) 942.2413

\section{Forbes Road}

Braintree. MA 0218

(617) 843.2383

\section{SUESCRIPTION SERMICES}

616 Carillon Tower West

(214) 387.2426

Suite 110.B

Diamond Hill Complex

2480 W. 26 th Ave.

(303) 433.3235

P.O. Box 92901

Los Angeles, CA 90009

(213) 772.2381
EBSCO Building

Red Bank, NJ 07701

(201) 741.4300

681 Market Street San Francisco, CA 94105 (415) $391 \cdot 3500$

Suite 204

8000 Forbes Piace

Springtield VA 22151

(703) $321.9630 / 321.7494$
17.19 Washington Ave. Tenafly, NJ 07670 (201) 569.2500

Six Thorncliffe Park Drive Toronto, Canada $\mathrm{M} 4 \mathrm{H} 1 \mathrm{H}_{3}$ (416) 421.9000

divinion of

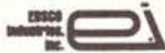

